\title{
Population dynamics and ecoparasitological surveys of Corophium volutator in coastal waters in the Bay of Mecklenburg (southern Baltic Sea)
}

\author{
Karin Meißner*, Andreas Bick \\ University of Rostock, Department of Zoology, Universitätsplatz 5, D-18051 Rostock, Germany
}

\begin{abstract}
The population dynamics of Corophium volutator (Pallas, 1766) were studied at 2 stations in virtually tideless water in the Bay of Mecklenburg (southern Baltic Sea). Particular attention was given to temperature, the main factor affecting reproductive and development processes. Infestation by parasites was one of various factors which was considered for explanation of variations in abundance in the course of the year. At both stations 2 generations were present during the reproduction period. These were called the spring generation and summer generation (with cohorts $I$ and II) in accordance with their occurrence. The greatest increase in abundance coincided with the appearance of the spring generation. Most of the overwintering individuals originated from summer generation I in both populations. Although reproductive activity was the same at both stations, the variations in abundance were completely different; the population at one station collapsed almost completely. Ecoparasitological analysis revealed that mortality in the extremely heavily infested spring generation was unusually high, and this had a direct impact on subsequent reproductive processes. The much more severe infestation at one station than at the other was found to be caused by a 4 -fold higher abundance of the wadden snail Hydrobia spp., which is the primary intermediate host of the larval trematodes found in $C$. volutator in these waters. The studies showed that parasite infestation is a factor that can affect population development. Therefore, ecoparasitological phenomena should be taken into account when interpreting data relating to population dynamics.
\end{abstract}

KEY WORDS: Corophium volutator Population dynamics - Parasites Digenetic trematodes Baltic Sea

\section{INTRODUCTION}

Species of the genus Corophium are among the most common members of the macrozoobenthos in many shallow waters and waddens, C. volutator (Pallas, 1766) sometimes achieving abundances of 100000 ind. $\mathrm{m}^{-2}$ (Möller \& Rosenberg 1982). These high abundances and the relative ease of sampling have made the species a popular object of marine biological research, and several authors have studied its population dynamics and reproduction (Segerstråle 1940, McLusky 1968, Nair \& Anger 1979). They have shown that reproduction starts in spring and finishes in autumn. Usually several broods are produced in the course of this

•E-mail: karin.meissner@biologie.uni-rostock.de season but, as a single female can produce more than one brood, they are sometimes quite difficult to differentiate (cf. Muus 1967, Fish \& Mills 1979) because recruitment events overlap. The reported frequencies of moulting, growth rates and brooding durations in the field are therefore based on estimates (Watkin 1941, Fish \& Mills 1979, Möller \& Rosenberg 1982). Studies on the population dynamics of $C$. volutator have explained the enormous variations in the abundance of this species as a result primarily of abiotic factors such as temperature, salinity, oxygen availability and sediment properties (Gee 1961, McLusky 1968, Murdoch et al. 1986, Raffaelli et al. 1991), and disturbance and predation have been held responsible for sudden decreases in population density (Boates \& Smith 1979, Peer et al. 1986, Matthews et al. 1992, Bick 
\& Arlt 1993). Muus (1967) reported particularly heavy parasite infestation in a population in Danish waters immediately before that population collapsed. Later, other authors also reported signs that population. development can be regulated by parasite infestation (Lauckner 1985, Jensen \& Mouritsen 1992, Bick 1994). However, these authors all (1) took only prevalence into account and (2) considered only the total population. The purpose of the study described here was to link investigations into population composition and development to ecoparasitological aspects. The generations produced in the course of a year were analyzed and examined for infestation in order to ascertain the effects of parasites on the various generations. Besides prevalence, additional parasitological parameters were used which permit clearer conclusions to be drawn regarding the effects of parasite infestation on the generations and the total population.

\section{MATERIALS AND METHODS}

The investigations were performed in virtually tideless water on the southern coast of the Bay of Mecklenburg, Germany, from March 30, 1994, to May 5, 1995. Samples were collected once monthly (exception: twice in June) at 2 stations (Fig. 1). Three parallel samples (quantitative samples) were obtained by corer $\left(78.5 \mathrm{~cm}^{2}\right)$ and sieved $(0.5 \mathrm{~mm}$ mesh). The sieved residue was fixed in $4 \%$ borax-buffered formaldehyde. Additional Corophium volutator samples (qualitative samples) were collected by means of manual dredge. The water temperature and salinity were measured at

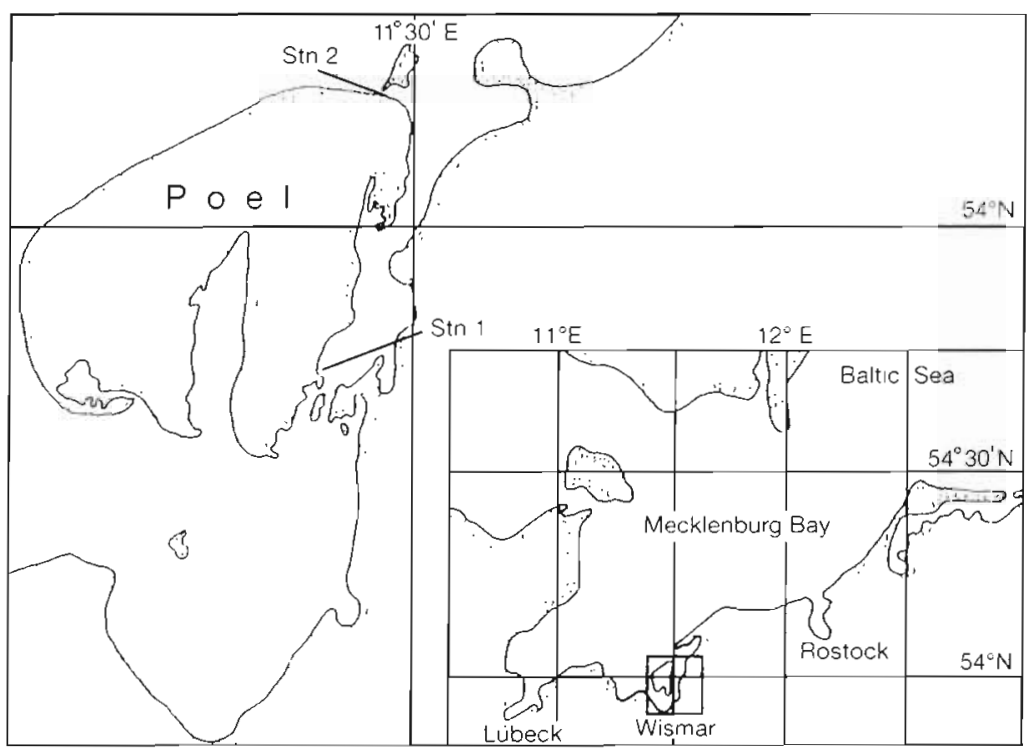

Fig. 1. Location of the investigation area and stations in the southern Baltic Sea each sampling, and sediment samples were also taken to determine the mean grain size, organic content and sorting coefficient.

The samples were analyzed for the quantitative and. qualitative composition of the macrozoobenthos under a stereoscopic microscope at $10 \times$ magnification. About 100 Corophium volutator individuals per sample and station were selected from the quantitative and qualitative samples and used to determine the following parameters: body length, sex, and, in females, oostegite development, egg number and egg development stage. All individuals smaller than $3.5 \mathrm{~mm}$ were regarded as juveniles as they could not be accurately sexed. Assignment of the individuals to the different generations was based on parameters such as animal size, the time at which ovigerous females appeared, the development stage of eggs in the marsupium, water temperature (permits estimation of egg and individual development duration) and intensity of infestation.

Corophium volutator specimens were examined for parasite infestation after the data for population dynamic studies had been obtained. The number of metacercarial cysts in the specimens was ascertained by completely dissecting the specimens with pincers under a stereoscopic microscope. Some cysts were measured and prepared for determination of the metacercaria they contained. Later we just assigned cysts to various types on the basis of their size and shape.

It seems appropriate here to define the meanings of some parasitological terms used in the present study (according to Margolis et al. 1982, amended):

- Prevalence: number of individuals of an infested host species divided by the number of hosts examined.

- Intensity: number of parasite individuals in each infested host in a sample.

- Mean intensity total number of parasite individuals in a sample of a host species divided by the number of infested individuals of the host species in the sample (= mean number of parasite individuals per infested host in a sample).

- Relative density: total number of parasite individuals in a sample of hosts divided by the total number of individuals of the host species (infested + uninfested) in the sample (= mean number of parasite individuals per host examined).

The frequency distribution of the infestation intensity was analysed statistically 


\section{RESULTS}

\section{Abiotic parameters}

Water temperatures scarcely differed between the 2 stations throughout the investigation (Fig. 2). The mean salinity was $13.4 \%$ at Stn 1 and $14.3 \%$ at Str 2 . Stn 1 was situated in a region of fine sand with a moderately graded sediment and a moderate organic content $(1.12 \pm 0.30 \%)$. The substrate at Stn 2 consisted of fine to very fine sand with a higher organic content $(2.33 \pm 0.40 \%)$.

\section{Faunistic composition and abundances}

Hydrobia spp and Nereis (Hediste) diversicolor were present as eudominant species at both stations throughout the investigation. The annual mean population density of Hydrobia spp. at Stn 1 was 10700 ind. $\mathrm{m}^{-2}\left(8200\right.$ to 30000 ind $\mathrm{m}^{-2}$ ) and was thus much higher than the 5600 ind. $\mathrm{m}^{-2}$ (2000 to 7500 ind. $\mathrm{m}^{-2}$ ) found at Stn 2. The hydrobiids in the samples collected in March 1994 were determined to species level. At Stn 1, 68 of the 70 specimens $(97.1 \%)$ belonged to the species $H$. ventrosa and 2 to $H$. ulvae. At Stn $2, H$. ventrosa accounted for $92.3 \%$ of the individuals. Abundances of $H$. diversicolor were about the same at both stations. No major fluctuations in population density were observed in the course of the year. The mean abundance of this species was 7800 ind. $\mathrm{m}^{-2}$ at $\operatorname{Stn} 2$ and 6800 ind. $\mathrm{m}^{-2}$ at $\mathrm{Stn} 1$

Corophium volutator was recorded as a dominant species only in the summer (June to August) of 1994. Further important species at the 2 stations included Heteromastus filiformis, Pygospio elegans, Tubifex costatus and, at Stn 1 in spring, Alkmaria romijni.

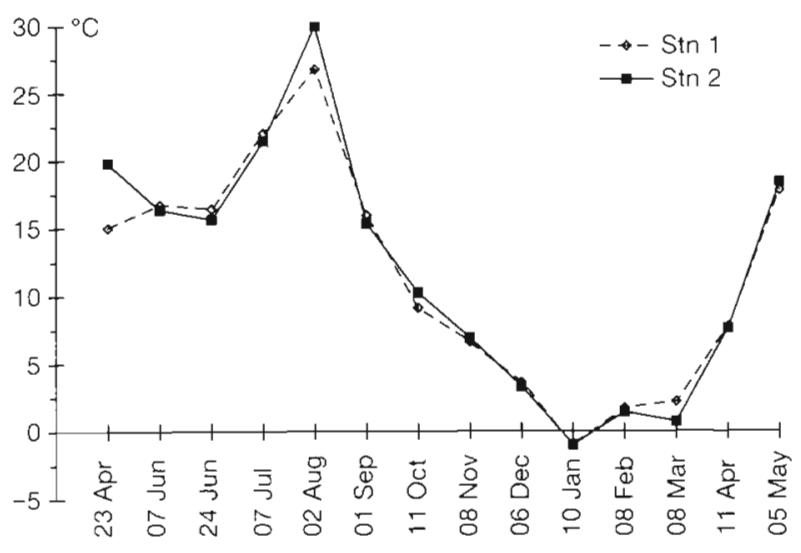

Fig. 2. Seasonal water temperature variations at Stns 1 and 2 in 1994-95

\section{Population development}

Two generations were produced in the course of the reproduction season at both stations during the year of the study. Each generation hatched at approximately the same time at both stations, and the growth of the individuals was also comparable at both (Figs. 3 \& 4).

All Corophium volutator collected at Stn 1 from March to April 1994 had overwintered and obviously belonged to different generations produced during the previous year. Their body length in March varied between 3 and $8 \mathrm{~mm}$, and the marsupia of some large females already contained eggs. The large individuals achieved fertility during the subsequent weeks, whereas the smaller individuals achieve reproductive size ( $5 \mathrm{~mm}$ ) until June. Thus, the juvenile $C$. volutator that emerged from May to June were the offspring of individuals that had overwintered and were the first

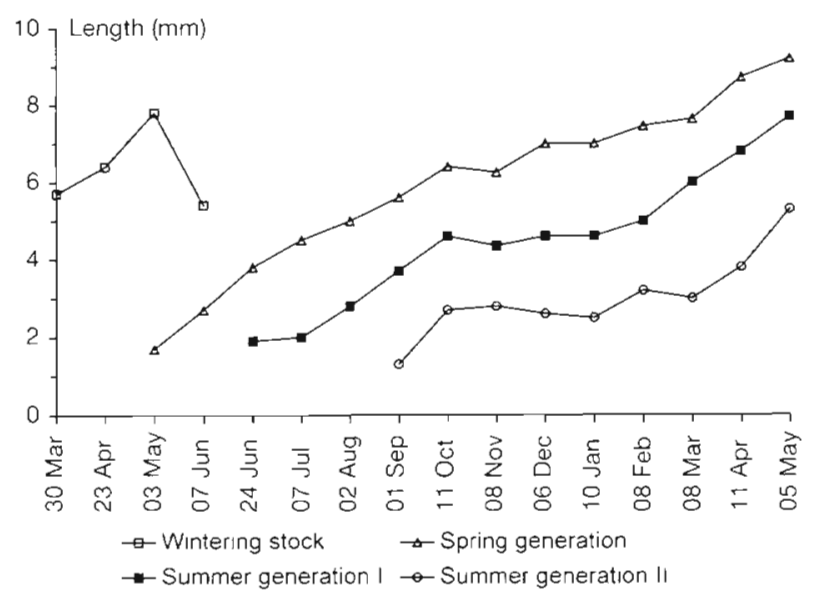

Fig. 3. Corophium volutator. Growth of the wintering stock and of the different generations at Stn 1 in 1994-95

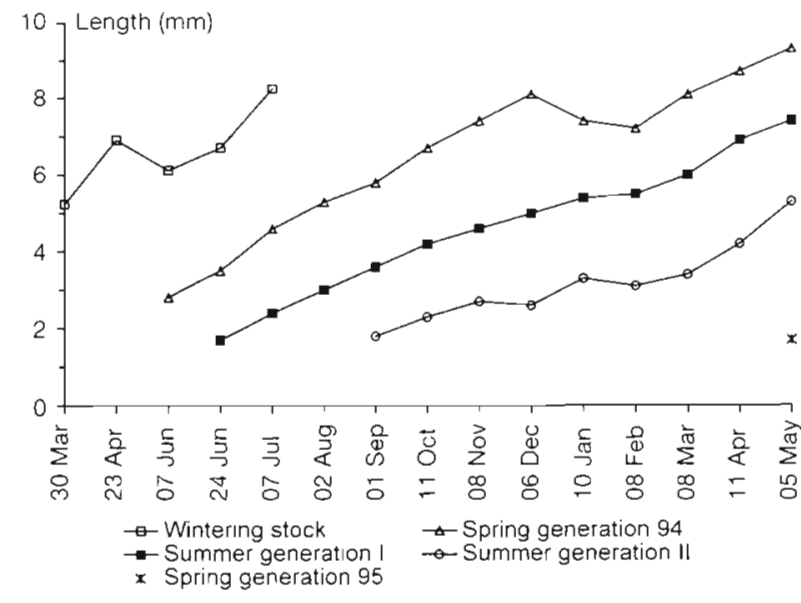

Fig. 4. Corophium volutator. Growth of the wintering stock and of the different generations at Stn 2 in 1994-95 
generation (spring generation) of 1994. This course of events is also reflected in the abundance data. the mean abundance at Stn 1 from March to April was 450 ind $\mathrm{m}^{-2}$, increased to 5900 ind. $\mathrm{m}^{-2}$ when the spring generation started to hatch in May and finally peaked at 33200 ind. $\mathrm{m}^{-2}$ when reproduction of the overwintered $C$. volutator reached its maximum in June (Fig. 5). This peak was the highest abundance recorded at Stn 1 in 1994. At this point, the individuals of the overwintered stock accounted for $15.8 \%$ of the total population (Fig. 6).

Since the Corophium volutator that had overwintered died after reproducing, most large individuals had vanished from the stock in June. The abundance decreased slightly to about 21000 ind. $\mathrm{m}^{-2}$ in this month. The samples collected in July contained no specimens that had overwintered.

When first observed in May, the individuals of the spring generation had a mean size of $1.7 \mathrm{~mm}$ (Fig. 3). The first ovigerous females of this generation appeared in late June, but were very sparse. The majority of the spring generation achieved reproductive maturity in July and August, when their mean body length varied between 4.5 and $5 \mathrm{~mm}$. The marsupia of the spring generation females contained substantially fewer eggs than had been found in those of the females that had overwintered (13 eggs per female compared with 36 eggs per female on average). Reproduction of the spring generation continued until October.

The second generation of the year, the summer generation, appeared very soon after the first ovigerous females had been observed in the spring generdtion. The summer generation could be broken down into 2 cohorts that were distinguished by the time at which they appeared. The first cohort (= summer generation I) developed from the early broods of the spring generation, but possibly contained a small number of individuals from the last brood of the overwintering stock of

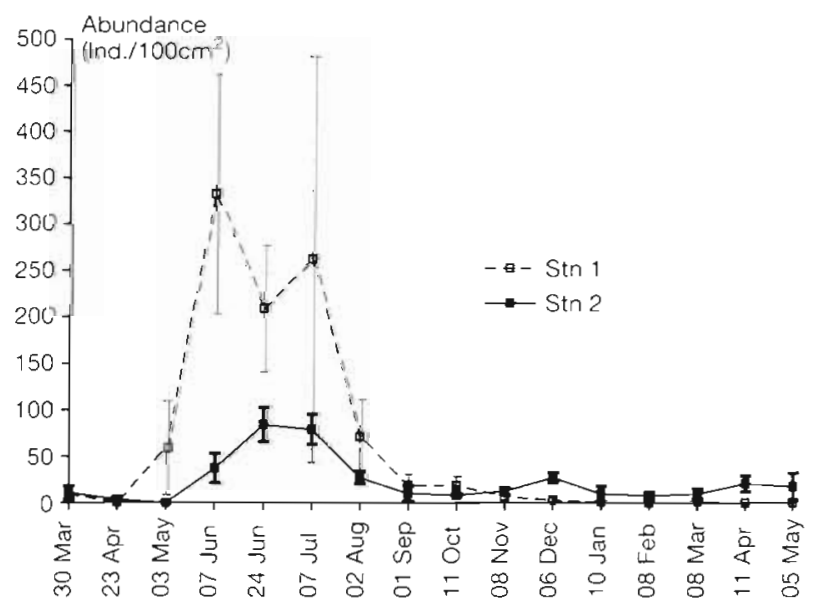

Fig. 5. Corophium volutator. Abundances $(\bar{x} \pm$ SD) in 1994-95

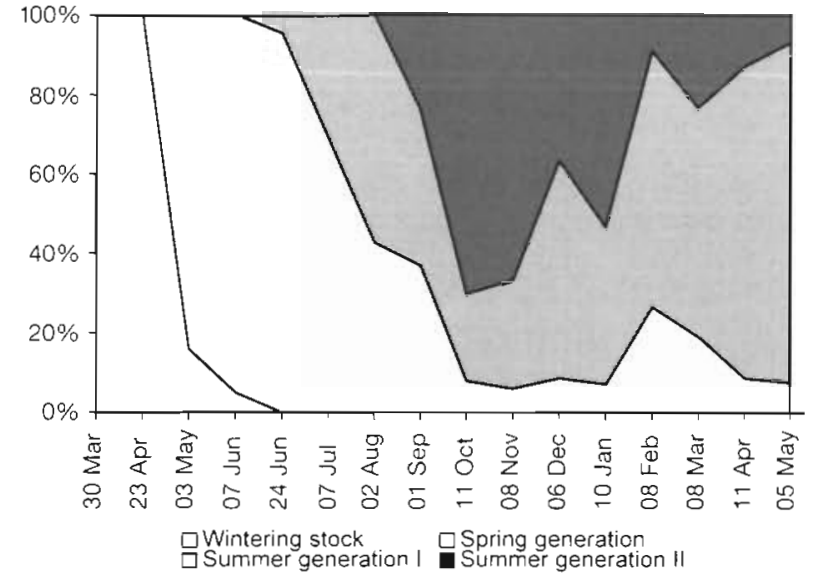

Fig. 6. Corophium volutator. Population structure at Stn 1 in $1994-95$

Corophium volutator. Although the latter belonged by definition to the spring generation, precise differentiation from summer generation I was impossible in this case. The hatching of summer generation I was also reflected in the abundance, which rose to 26150 ind. $\mathrm{m}^{-2}$ in July (Fig. 5), when summer generation I accounted for $30.8 \%$ of the total population (Fig. 6). Although a few isolated females of this generation achieved sexual maturity by September, the majority did not in 1994 . This means that the production of a third generation might theoretically have been possible. However, as it would have consisted of only a very few individuals which, moreover, would have been indistinguishable from the last $C$. volutator of the summer generation, the possibility of a third generation was ignored.

The second cohort of the summer generation (= summer generation II) developed from the late broods of the spring generation. Their presence became apparent in September (Fig. 6) due to an increased abundance of individuals smaller than $2.5 \mathrm{~mm}$. The abundance of the total population decreased to 1870 ind. $\mathrm{m}^{-2}$ in this month, however, so even the autumnal reproduction had little quantitative impact (Fig. 5). The abundance of the spring generation at this time was 690 ind. $\mathrm{m}^{-2}$ compared with 18100 ind. $\mathrm{m}^{-2} 2 \mathrm{mo}$ earlier (Fig. 7). The abundance of summer generation I had also declined from 8050 ind. $\mathrm{m}^{-2}$ in July to around 700 ind. $\mathrm{m}^{-2}$ (Fig. 8).

Total population abundance continued to sink during the subsequent months until finally dropping below the detectibility limit of 42.5 ind. $\mathrm{m}^{-2}$ set by the sampling method used during the study. The proportion of summer generation II in the total population decreased particularly rapidly from November to February, so that summer generation I was the predominant generation among the population from January 1995 onwards (Fig. 6) 


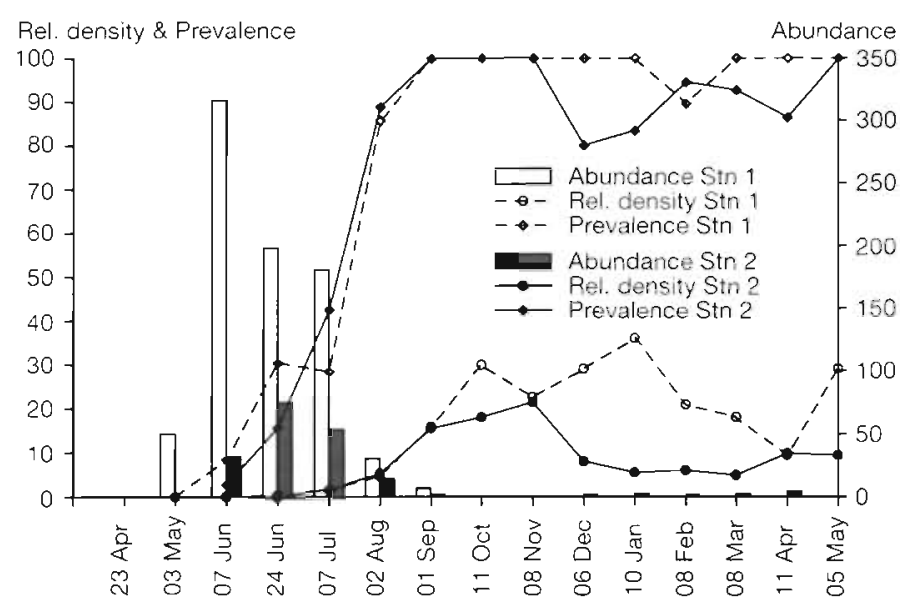

Fig. 7. Corophium volutator. Abundance (ind. per $100 \mathrm{~cm}^{2}$ ) and prevalence $(\%)$ of the spring generation and relative density of metacercarial cysts (mean no. of parasites per host) in this generation in 1994-95

The succession of the generations at Stn 2 followed almost the same pattern as at Stn 1 (Fig. 9), but the abundances achieved in summer were much lower (Fig 5). However, it cannot be said that the population collapsed. At this station, the spring generation was first observed in June, but this was almost certainly because no samples were collected there in May. The emergence of the spring generation raised the total population abundance from 340 ind. $\mathrm{m}^{-2}$ in April to 3700 ind. $\mathrm{m}^{-2}$ in June (Fig. 5). The first individuals of summer generation I were observed in late June, when the abundance at this station reached its highest level ( 8400 ind. $\mathrm{m}^{-2}$ ) during the study. The abundance was similarly high in July, but then declined to reach a provisional minimum of 810 ind. $\mathrm{m}^{-2}$ in October (Fig. 5). This decrease in abundance was mainly due to a large reduction in the presence of

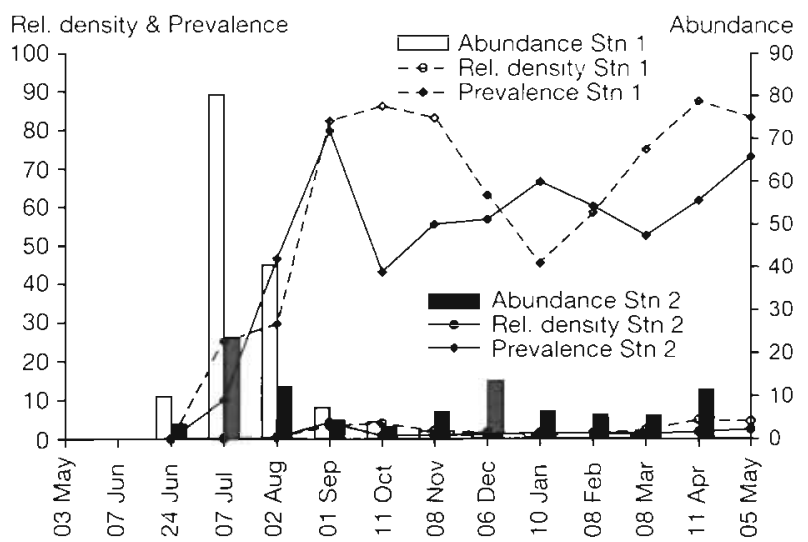

Fig. 8. Corophium volutator. Abundance (ind. per $100 \mathrm{~cm}^{2}$ ) and prevalence $(\%)$ of the summer generation $\mathrm{l}$ and relative density of metacercarial cysts (mean no. of parasites per host) in this generation in 1994-95 individuals from the spring generation, but also to a reduction in the abundance of summer generation I. The highest abundances reached by the spring generation and summer generation, respectively, were 7500 ind $\mathrm{m}^{-2}$ (late June) and 2400 ind $\mathrm{m}^{-2}$ (July). These had decreased to 60 and 280 ind. $\mathrm{m}^{-2}$, respectively, in October (Figs. $7 \& 8$ ).

The number of offspring produced in autumn (= summer generation II) was also lower than that produced in spring and summer (juveniles of the spring generation and summer generation I) at Stn 2, but this generation constituted the majority of the total population in October (Fig. 9). The last, occasional ovigerous females at this station were found in October. In November and December, the abundance of the summer generation cohorts increased (Fig. 8) and led to an increase in total population abundance.

The samples collected in January contained almost no individuals of summer generation II (Fig. 9), and the abundance of summer generation I had also dropped by almost $50 \%$ (Fig. 8). Owing to these reductions, the abundance of the total population also decreased (Fig. 5), but then remained relatively constant ( 860 ind. $\mathrm{m}^{-2}$ on average) until March.

\section{Parasite infestation}

The microphallids found in Corophium volutator were identified as the species Levinseniella brachysoma (Creplin, 1937) and Maritrema subdolum (Jägerskiold, 1908), the latter species predominating at both stations (94.5\% at Stn 2 and $64.9 \%$ at $\mathrm{Stn} 1)$. However, since only a relatively small sample of metacercarial cysts were used to determine the trematode species, it

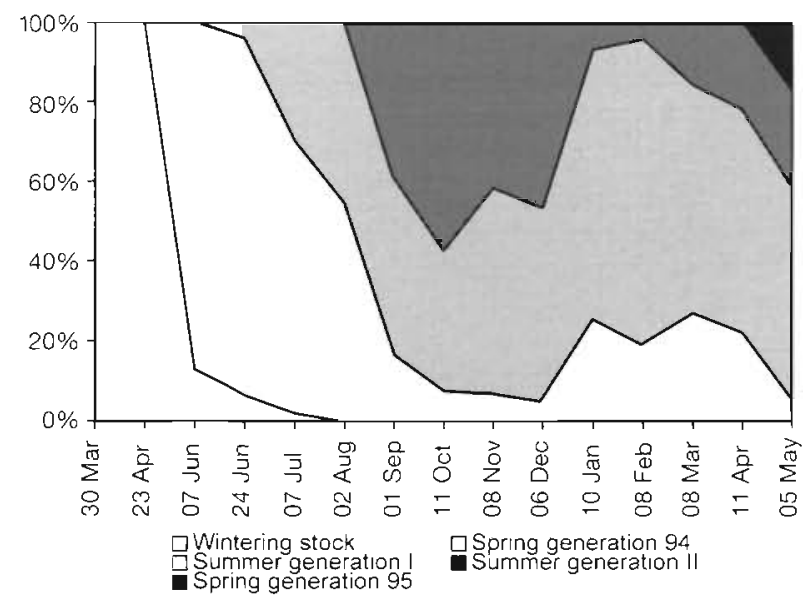

Fig. 9. Corophium volutator. Population structure at Stn 2 in $1994-95$ 


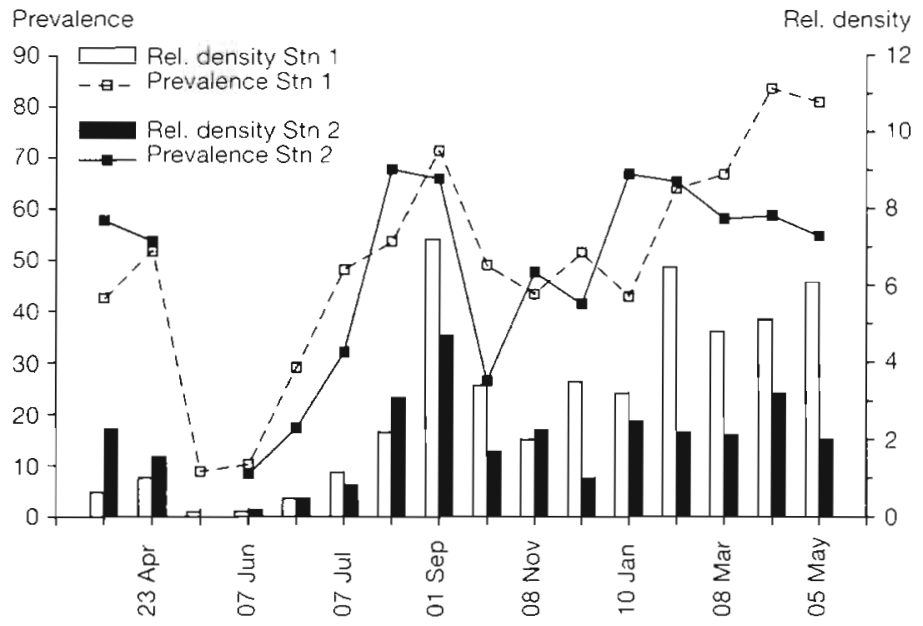

Fig. 10. Corophium volutator. Prevalence (whole population in \%) and relative density of metacercarial cysts (mean no. of parasites per host) in this generation in 1994-95

is quite possible that the C. volutator were also infested with further trematode species.

The fluctuations in prevalence among the total population were very similar at both stations (Fig. 10). The lowest values were recorded in May and June, but thereafter prevalence increased very rapidly so that at least two-thirds of all individuals had become infested in September. After decreasing distinctly again in October, it then gradually increased up to the end of the investigation period.

Comparison of the relative densities of parasites revealed differences between stations in the mean number of parasites per host (Fig. 10). Except in November 1994, the relative density of parasites among the total population was distinctly higher at Stn 1 than at Stn 2 from September onwards. For example, in September, the month with the highest relative density of parasites among the total population, the mean number of metacercarial cysts per individual was 7.2 at Stn 1 and 4.7 at Stn 2. It was also noted that the prevalence and relative density values at Stn 1 were distinctly higher in spring 1995 than in spring 1994. At Stn 2, in contrast, both parameters returned to the values of the previous year after winter (Fig 1.0).

Further differences are found by considering the generations separately. Prevalence among the spring generation was $100 \%$ at both stations in September, i.e. metacercarial cysts were found in all individuals of this generation (Fig 7). This high value remained virtually unchanged until the end of the study at Stn 1, whereas lower prevalences were recorded at Stn 2 from December onwards. Analysis of the relative density of parasites casts even more light on the degree of infestation (Fig. 7). Relative densities were high in the spring generations at both stations from September on.
From September to May 1995, an average of 23.4 metacercarial cysts per individual were found in Corophium volutator of the spring generation at Stn 1 and an average of 10.9 at Stn 2, i.e. the specimens at Stn 1 contained more than twice as many cysts as those at Stn 2.

The prevalences and relative densities were much lower in summer generation I than in the spring generation at both stations (Fig. 8). At Stn 1, these 2 parameters increased to annual peaks of $85 \%$ and 4.1 , respectively, in October. Similar values were recorded in November, but then the prevalence in particular decreased appreciably. However, prevalence increased again from February to the end of the study, rising to over $80 \%$ in April. At Stn 2 , the highest values of the year, $80 \%$ and 4.3, respectively, were recorded in September. At this station, however, the prevalence had already dropped to $43 \%$ in the following month, and the relative density of the parasites had decreased to 0.8 .

Metacercarial cysts were rarely found in individuals of summer generation II, so that the mean relative density was 0.4 at both stations for these individuals. Prevalence was about $25 \%$ in these individuals throughout the study period.

The intensities of infestation of the spring generation at Stn 1 were analysed statistically. Comparison of the theoretical and empirical distributions of infestation intensity in early June showed that infestation events are independently binomially distributed random events of equal probability. Comparison of the empirical distribution of the infestation intensity in September with the corresponding binomial distribution (Fig. 11) revealed that (1) infestation intensities $\leq 10$ were 4.7 times more common than theoretically expected; (2) for infestation intensities from 11 to 20 the theoretical expectation was 1.5 times higher than the

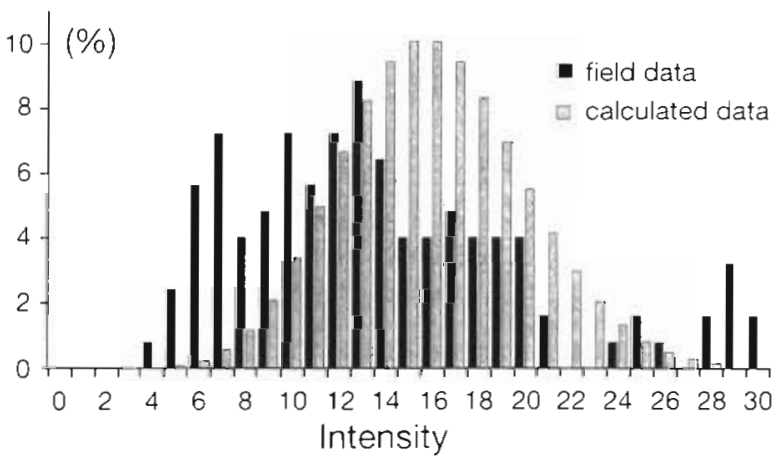

Fig. 11. Corophium volutator. Comparison of the theoretical and observed frequency distribution (\%) of infestation intensity among the spring generation at Stn 1 in September 
empirical value, and (3) for infestation intensities $>20$ the field data were, on the average, in good accordance with the expected values. The relatively frequent occurrence of very high infestation intensities was striking

\section{DISCUSSION AND CONCLUSIONS}

Many studies have shown that the abundance and population development of Corophium volutator are governed by several factors. Salinity and substrate quality have repeatedly been shown to be the decisive abiotic factors. McLusky (1967) found that $C$. volutator can survive salinities between 2 and $50 \%$, but that abundances are depressed below 5\%. Reproduction appears to be most successful at salinities between 5 and $20 \%$. During our studies, salinities varied between 8.5 and $17.4 \%$ at Stn 1 and between 10.0 and $18.1 \%$ at Stn 2 and were thus within the optimal range for population development. This also applies to the sediment quality $C$ volutator prefers muddy and fine sandy substrates with a moderate to fairly high organic content in shallow waters (Segerstrale 1940, Gee 1961). The parameters of the sediments at the sampling stations showed that the substrate was suitable for colonization at both stations

Temperature is the most important variable regulating reproductive activity and individual development in Corophium volutator populations. Apart from determining the onset of the reproductive season, it also determinates duration of brood development, growth rate and thus the moult frequency, and the time at which sexual maturity is reached (Segerstrale 1940 , McLusky 1968, Nair \& Anger 1979).

Since the water temperatures had risen to over $15^{\circ} \mathrm{C}$ at both stations in March 1994, conditions were favourable for reproduction among the Corophium volutator individuals that had overwintered. The consequence was the huge increase in abundance recorded particularly at Stn 1 during the subsequent weeks. Two possible explanations can be offered for the slight reduction in abundance recorded at Stn 1 in late June: our analysis of the composition of the population shows that the overwintering stock of $C$. volutator died after reproducing in spring (Fig. 6). Similar mortality of individuals after overwintering has also been reported by various other authors (Segerstråle 1940, Möller \& Rosenberg 1982, Murdoch et al, 1986, Peer et al. 1986). On the other hand, Meadows \& Reid (1966) reported that juvenile individuals, owing to their low weight, can easily be carried away to other habitats. It therefore also seems possible that the juvenile stocks at our stations had been decimated by mortality and drifting.
Under normal circumstances, the spring generation is that generation in the life cycle of Corophium volutator populations that continues reproducing through the summer until well into autumn and, by its offspring (the summer generation) ensures the continued existence of the population until the onset of reproductive activity during the subsequent spring. The females of this generation are able to produce several consecutive broods (Segerstråle 1940). A linear relationship has been reported between female body length and brood size (number of eggs) (Fish \& Mills 1979, Bick 1994). At low temperatures, up to $4 \mathrm{wk}$ may elapse between deposition of the eggs and hatching, but most authors assume that hatching takes $2 \mathrm{wk}$ in summer (Watkin 1941, Fish \& Mills 1979, Möller \& Rosenberg 1982).

At Stn 1, the spring generation started reproducing in June. As the females were still quite small when reproduction started, their marsupia contained considerably fewer eggs than the females that had overwintered and reproduced in March and April. Owing to the high water temperatures in July and August, the eggs developed quickly and led to the very rapid appearance of the next (summer) generation. Although the spring generation continued to reproduce in August and September, the abundance of the whole population declined until autumn to a level recorded in early spring. The reason for this was the disappearance of individuals of the spring and summer generation I from the population. The diminishing abundance of the spring generation was accompanied by a decline in reproductive success of the population as a whole as the number of individuals actually reproducing became progressively smaller. Hence, the abundance of the summer generation, and particularly of cohort II. was lower than that of the spring generation from the very start.

The succession of generations at Stn 2 was virtually the same as at Stn 1. This was scarcely surprising as the stations were only a few kilometres apart and the water temperatures were almost identical. Our observation of 2 generations per year is in line with the results reported by Watkin (1941) and Fish \& Mills (1979) for the Dovey estuary in Scotland, Möller \& Rosenberg (1982) for Swedish waters and Peer et al. (1986) for Chignecto Bay in the Bay of Fundy, Canada. Describing the results of studies undertaken in Denmark, Muus (1967) allowed for the possibility of 4 generations per year, but emphasized the difficulty in determining the number of generations. Segerstralle (1940) and McLusky (1968) both reported observing only 1 generation per year on the Finnish and Scottish coasts.

The pattern of abundance development at Stn 1 was quite different to that at $\operatorname{Stn} 2$. The abundances of the overwintering stocks at the 2 stations were quite simi- 
lar in 1994, and the number of eggs produced by the females and the proportion of ovigerous females in the overall population in spring were also comparable. Consequently, an increase in abundance similar to that observed at Stn 1 might have been expected following the start of the reproductive phase at Stn 2 . Since this failed to materialize, the summer abundance peaks being much lower, either mortality was higher among the offspring at Stn 2 or migration had taken place.

In August and September, the abundance decreased at $\operatorname{Stn} 2$ in the same way as at $\operatorname{Stn} 1$. The majority of the spring population vanished from the population, but the abundance of summer generation I and the number of individuals hatching as summer generation II were also low (Figs. 6, $7 \& 8$ ).

The increase in total abundance recorded at Stn 2 in November and December (Fig. 5) can be explained only by an immigration of individuals as a result of low water temperatures, for instance from nearby shallower areas. Möller \& Rosenberg (1982) also suspected that Corophium volutator migrated to deeper waters during the winter.

Comparison of our abundance data with findings reported by other authors immediately reveals one striking difference: most studies into the population dynamics of Corophium volutator have reported that abundances increase during the main reproductive season from May to September (Segerstrăle 1940, McLusky 1968, Murdoch et al. 1986, Peer et al. 1986, Matthews et al. 1992). Ignoring the possibility of immigration events and assuming that 2 generations are produced per year, this increase in abundance would be due to reproduction initially by the overwintering population and subsequently by the spring generation. The abundance should not decrease appreciably until the reproductive season is over as, according to Watkin (1941), most of the spring generation die after November In 1994, however, a considerable drop in abundance was recorded much earlier, i.e from July to September, at Stns 1 and 2. Consequently, it can be assumed that the normal development of the populations at these stations was somehow negatively affected. Various possible causes must be considered.

In the first place, changes in sediment quality and salinity fluctuations cannot have been responsible for the decrease in abundance. However, since the water body in shallow regions can gain and lose heat very rapidly as the air temperature changes, very high temperatures are a potential cause of increased mortality in summer. The water temperatures measured at sampling Stns 2 and 1 in August were $30.0^{\circ} \mathrm{C}$ and $26.8^{\circ} \mathrm{C}$, respectively According to Mills \& Fish (1980), Corophium volutator can tolerate much higher temperatures, up to $38^{\circ} \mathrm{C}$, in the salinity range from 10 to $20 \%$. Moreover, our own experimental findings show that juvenile individuals are harmed more severely by high temperatures than adults. The former are obviously less tolerant to changes in abiotic factors. High temperatures are also associated with the danger of oxygen deficiency in the sediment. Although oxygen concentrations were not measured during our study, the black sulphidic layer was not observed at the sediment surface or at the burrowing depth of $C$. volutator during sample collection.

Migrating wading birds and fishes have often been discussed as possible factors affecting the population development of Corophium volutator (Peer et al. 1986, Jaquet \& Raffaelli 1989, Mattila \& Bonsdorff 1989, Matthews et al. 1992, Mattila 1992, Daborn et al. 1993). Although sampling Stns 1 and 2 are located in the vicinity of major resting and breeding grounds for limicoles, they are scarcely suitable as resting grounds for waders owing to the water depth of, usually, 0.5 to $0.6 \mathrm{~m}$, although flocks of mute swan visit Stn 1 in winter. Large numbers of small fishes (mainly Pomatoschistus sp.) were observed when collecting samples in summer. Field experiments led Jaquet \& Raffaelli (1989) to the conclusion that Pomatoschistus minutus, even if present in maximum abundances, would not be able to affect either density or structure of $C$. volutator populations.

It is scarcely conceivable that Carcinus maenas, Crangon crangon, Arenicola marina, Cerastoderma edule or Cerastoderma lamarcki would have any appreciable impact either through predation or disturbance effects as these species were found, if at all, only occasionally at the sampling stations. The polychacte Nereis (Hediste) diversicolor was abundant at both stations, however, and both Rönn et al. (1988) and Bick \& Arlt (1993) have shown that this species, depending on its abundance, exercises predation pressure on Corophium volutator, simultaneously inducing its emigration. The abundances of this polychaete in June 1994 were about 11000 ind. $\mathrm{m}^{-2}$ at Stn 1 and 8000 ind. $\mathrm{m}^{-2}$ at Stn 2 owing to the reproductive activity of $N$ diversicolor during the spring. At Stn 1 the average body length of $N$. diversicolor was $0.98 \mathrm{~cm}$ in July, $0.74 \mathrm{~cm}$ in August and $1.17 \mathrm{~cm}$ in September Therefore the population contained a large number of juveniles which do not feed preferentially on $C$. volutator (Goerke 1971). At Stn 2 the average body length of the polychaete was $2.05 \mathrm{~cm}$ in. July, $2.05 \mathrm{~cm}$ in August and $1.47 \mathrm{~cm}$ in September In the case of this station it cannot be precluded that $N$ diversicolor played a role in reducing the abundance of $C$. volutator.

Molluscs of the genus Hydrobia were also an important part of the fauna at both stations. The significance of $H$. ventrosa for Corophium volutator lies not in trophic relations or competition for food, but has a parasitological nature (Lopez \& Levinton 1978). The 
molluscs of the genus Hydrobia are intermediate hosts of various digenetic trematodes (e.g microphallids), including those that use $C$. volutator as a secondary intermediate host. Studying hydrobiids in the Danish Waddenmeer, Lauckner (1986) noted that all mudsnails ( $H$. ulvae) with shells over $3.7 \mathrm{~mm}$ high had been infested. The microphallids accounted for $77 \%$ of the parasites found in all infested specimens. S. Probst (pers comm.) confirmed similar observations for $H$. ventrosa larger than $2.5 \mathrm{~mm}$ in regions near Stns 1 and 2 in the summer of 1995. In view of the abundance of hydrobiids and the fact that over 200 cercariae can be found in a single mudsnail, these data obviously signify a huge quantitative potential for infestation.

After leaving their primary intermediate host (molluscs such as Hydrobia spp.), the cercariae of both trematode species actively seek their secondary intermediate hosts (Corophium volutator and other crustaceans), which they enter and where they then form cysts. The escape of the cercariae from their primary intermediate hosts, their behaviour in the water (of decisive importance for locating suitable hosts) and their life-span are governed primarily by temperature (Rees 1948, Shostak \& Esch 1990). Examination of the water temperatures measured during the study period shows that $C$. volutator could have been infested from April to September 1994 and then, at the latest, May 1995.

The low relative densities of the parasites and their prevalences within the total population in May and June are obviously due to the predominance of still uninfested juveniles of the spring generation and the death of infested adults that had overwintered (Figs. 6 \& 9). Bick (1994) also reported that prevalences were lowest at the beginning of the reproductive season. Thereafter, increasing numbers of individuals were infested with cercariae with increasing frequency until infestation peaked in September. In October, the number of severely infested individuals had decreased again relative to the number of uninfested and slightly infested specimens in the population. The lower overall level of infestation in October was due to the absence of the severely infested Corophium volutator from the spring generation.

The differences between the levels of infestation in successive generations depend on the times at which the generations hatch. The emergence of cercariae, including those infesting Corophium volutator, from their primary intermediate hosts can be expected to peak in July and August. This increases the probability of infestation of $C$. volutator by trematode larvae at that time. Consequently, the spring generation is exposed to cercaria infestation for a considerable time, whereas the summer generation II was just hatching as the abundance of cercariae started to decline. How- ever, besides the duration of development the phase of development of $C$. volutator also plays a role. According to Meadows \& Reid (1966), only large individuals are regularly found outside of their burrows, younger specimens emerging only in response to mechanical disturbance and burrowing themselves in again as quickly as possible. Since the specimens are infested in the water near the sediment surface (G. Lauckner pers. comm.), the relative density and prevalence of parasites should be highest in the generation with the largest individuals. This generation was the spring generation.

Both the prevalence and the relative density of the parasites in the population increased in winter. This was due to the decreasing abundance of the very small individuals of summer generation II, probably owing to their low tolerance of low water temperatures. Clear differences between the levels of infestation at the 2 sampling stations were only revealed by comparison of the relative density of parasites. The values for the whole population at Stn 1 were as a rule distinctly higher than for the population at Stn 2. This was primarily a consequence of the different abundances of the primary intermediate host. The mean abundance of Hydrobia spp. at Stn 1 (20700 ind. $\mathrm{m}^{-2}$ ) during the study period was about 3.7 times as high as at Stn 2 (5600 ind $\mathrm{m}^{-2}$ ). Assuming that the snails were infested to a similar degree at both stations, this implies that the abundance of cercariae and also the probability of infestation of Corophium volutator was correspondingly higher at Stn 1.

Thus, there are 2 weighty reasons for assuming that trematode infestation can influence the development of Corophium volutator populations: (1) the decrease in abundance was greatest in the generation in which the relative density of parasites was highest (i.e. the spring generation), and (2) the decrease in abundance was smallest at the station at which the relative density of parasites was lowest (i.e. Stn 2).

It was also observed that the reduction in abundance was particularly pronounced at the same time as the prevalence increased particularly rapidly. This phenomenon could be seen in the spring generation, cohort I of the summer generation and, consequently, also for the population as a whole. In other words, the more individuals that were infested, the more individuals died.

The statistical analysis of the intensity of infestation among the spring generation at Stn I supports the assumption that the decreasing abundance and high infestation intensity in this generation are closely linked. Infestation proved to be a random event, and subsequent infestations are independent of previous ones. Comparison of the frequency distribution of infestation intensity expected on this basis with that 
actually found in September showed that individuals with high infestation intensities (14 to 22) were distinctly less common in September than theoretically expected (Fig. 11). Animals with low infestation intensities were therefore disproportionately common in the spring generation.

High intensities of infestation may kill Corophium volutator (Lauckner 1987, Bick 1994) through at least 2 mechanisms. (1) Infestation modifies the behaviour of the host (Holmes \& Bethel 1972, Schaub 1989, Hurd 1990 ) in such a way that it becomes easy prey for its predators. Such behavioural modifications favouring predation on infested specimens in the population are quite conceivable in the case of $C$. volutator. (2) Severe infestation may lead directly to the death of the host. In such cases, the host is unable to sustain the functions of its organs owing to the large number of metacercarial cysts and the action of lytic enzymes and therefore dies. In some severely infested $C$, volutator specimens from the sampling stations the entire middle and rear parts of the body were filled with metacercarial cysts. Lauckne. (1990) suspects that small individuals may be particularly endangered by high parasite densities.

Obviously, high levels of infestation are not always disadvantageous for the infested host as a few extremely severely infested individuals of the spring generation were still present in the population in spring 1995 . The response to infestation by larval trematodes could vary from individual to individual, depending for instance on the condition and age of the host, the parasite species (Lauckner 1986) and the intensity of infestation relative to host size (Lauckner 1988). However, for most Corophium volutator, high intensities of infestation appear to have lethal consequences. Our studies have shown that consideration of parasitological data can help to draw clearer conclusions from analyses of population dynamics. However, this necessitates a detailed analysis of the composition of the population and the use of several parasitological parameters. Ecoparasitological surveys should be an integral part of studies dealing with the biology and ecology of marine animal species

\section{LITERATURE CITED}

Bick A (1994) Corophum volutator (Corophiidae: Amphipoda) as an intermediate host of larval Digenea-an ecological analysis in an coastal region of the southern Baltic. Ophelia $40(1): 27-36$

Bick A, Arlt G (1993) The influence of Hediste diversicolor (O. F. Müller, 1776) on the macro- and melozoobenthos of a shallow water area of Mecklenburg Bay (Western Baltic Sea). Rostock Meeresbiol Beitr 1:9-24

Boates JS, Smith PC (1979) Length-weight relationships, energy content and the effects of predation on Corophium voiutator (Pallas) (Crustacea: Amphipoda). Proc NS Inst Sci 29:489-499
Daborn GR, Amos LA, Brylinsky M, Christian H, Drapeau G (1993) An ecological cascade effect: migratory birds affect stability of intertidal sediments. Limnol Oceanogr 38(1): 225-231

Fish JD, Mills A (1979) The reproductive biology of Corophium volutator and C. arenarium (Crustacea: Amphipoda). J Mar Biol Assoc UK 59:355-368

Gee JM (1961) Ecological studies in South Benfleet Creek with special reference to the amphipod genus Corophium. Naturalist 30:291-309

Goerke H (1971) Die Ernährungsweise der Nereis-Arten (Polychaeta, Nereidae) der deutschen Küsten. Veröft Inst Meeresforsch Bremerh 13:1-50

Holmes JC, Bethel WM (1972) Modification of intermediate host behaviour by parasites. Behavioural aspects of parasite transmission. Academic Press, London, p 123-149

Hurd H (1990) Physiological and behavioural interactions between parasites and invertebrate hosts. Adv Parasitol 29 $273-318$

Jaquet N, Rafaelli D (1989) The ecological importance of the sand goby Pomatoschistus minutus (Pallas). J Exp Mar Biol Ecol 128:147-156

Jensen KT, Mouritsen KN (1992) Mass mortality in two common soft-bottom invertebrates, Hydrobia ulvae and Corophium volutator - the possible role of trematodes. Helgol Meeresunters 46:329-339

Lauckner G (1985) Diseases of Aves (marine birds). In: Kinne $O$ (ed) Diseases of marine animals, Vol IV (2). Biologische Anstalt Helgoland, Hamburg, p 627-643

Lauckner G (1986) Ecological effects of larval trematode infestation on littoral marine invertebrate populations. Int J Parasitol 17:391-398

Lauckner G (1987) Einfluß von Trematodenbefall auf die Populationsdynamik der Strandkrabbe (Carcinus maenas). Jahresber Biologische Anstalt Helgoland, p 16-18

Lauckner G (1.988) Effects of parasites on juvenile Wadden Sea invertebrates. In: Tougaard S, Asbirk S (eds) Proc 5th Int Wadden Sea Symposium (Esbjerg, 1986). Esbjerg, p 103-121

Lauckner G (1990) Parasiten-ihr Einfluß im Ökosystem Wattenmeer. In: Lozan JL, Lenz W, Rachor E, Watermann $B, v$ Westernhagen $\mathrm{H}$ (eds) Warnsignale aus der Nordsee. Verlag Paul Parey, Berlin, p 219-230

Lopez GR, Levinton JS (1978) The availability of microorganisms attached to sediment particles as food for Hydrobia ventrosa Montague (Gastropoda: Prosobranchia). Oecologia 32:263-275

Margolis L, Esch GW, Holmes JC, Kuris AM, Schad GA (1982) The use of ecological terms in parasitology (Report of an ad hoc commuttee of the American Society of Parasitologists). J Parasitol 68(1):131-133

Matthews SL, Boates JS, Walde SJ (1992) Shorebird predation may cause discrete generations in an amphipod prey. Ecography 15:393-400

Mattila J (1992) The effect of habitat complexity on predation efficiency of perch Perca fluviatilis L. und ruffe Gymnocephalus cernuus (L.). J Exp Mar Biol Ecol 157: $55-67$

Mattila J, Bonsdorff E (1989) The impact of fish predation on shallow soft bottoms in brackish waters (SW Finland); an experimental study. Neth J Sea Res 23(1):69-81

McLusky DS (1967) Some effects of salinity on the survival, moulting, and growth of Corophium volutator (Amphipoda). J Mar Biol Assoc UK 47:607-617

McLusky DS (1.968) Some effects of salinity on the distribution and abundance of Corophium volutator in the Ythan estuary. J Mar Biol Assoc UK 48:443-454 
Meadows PS, Reid A (1966) The behaviour of Corophium volutator (Crustacea: Amphipoda). J Zool, Lond 150:387-399

Mills A. Fish JD (1980) Effects of salinity and temperature on Corophium volutator and C. arenarium (Crustacea: Amphipoda), with particular reference to distribution. Mar Biol 58:153-161

Möller P, Rosenberg R (1982) Production and abundance of the amphipod Corophum volutator on the west coast of Sweden. Neth J Sea Res 16:127-140

Murdoch MH, Bärlocher F, Laltoo ML (1986) Population dynamics and nutrition of Corophium volutator (Pallas) in the Cumberland Basin (Bay of Fundy). J Exp Mar Biol Ecol 103:235-249

Muus BJ (1967) The fauna of Danish estuaries and lagoons. Medd Dan Fisk-Havunders N S 5:1-316

Nair KKC, Anger K (1979) Life cycle of Corophium insidiosum (Crustacea, Amphipoda) in laboratory culture. Helgoländer Wiss Meeresunters 32:279-294

Peer DL, Linkletter LE, Hicklin PW (1986) Life history and reproductive biology of Corophium volutator (Crustacea: Amphipoda) and the influence of shorebird predation on population structure in Chignecto Bay, Bay of Fundy, Canada. Neth J Sea Res 20(4):359-373

Raffaelli D, Limia J, Hull S, Pont S (1991) Interactions between the amphipod Corophium volutator and macro-

Responsible Subject Editor O. Kinne, Oldendorf/Luhe, Germany algal mats on estuarine mudflats. J Mar Biol Assoc UK $71(4): 899-908$

Rees G (1948) A study of the effect of light, temperature and salınity on the emergence of Cercana purpurae LEBOUR from Nucella lapıllus (L.). Parasitology 38:228-242

Ronn C, Bonsdorff E, Nelson WG (1988) Predation as a mechanism of interference within infauna in shallow brackish water soft bottoms; experiments with an infauna predator. Nercis diversicolor O. I: Möller. J Exp Mar Bıol Ecol 116: $143-157$

Schaub GA (1989) Auswirkungen von Parasiten auf das Verhalten ihrer Wirte. Biol Unserer Zeit 19(6):196-202

Segerstråle SG (1940) Zur Biologie des Amphipoden Corophium volutator, nebst Angaben über die Entwicklung und Rückbildung der Oostegitenborsten bei dieser Art Studien über die Bodentierwelt in südfinnländischen Küstengewässern VI. Soc Sci Fenn Comment Biol VI] $16: 1-40$

Shostak AW, Esch GW (1990) Photocycle-dependent emergence by Cercariae of Halipegus occidualis from Helisoma anceps, with special reference to cercarial emergence patterns as adaptations for transmission. J Parasitol $76(6): 790-795$

Watkin EE (1941) The yearly life cycle of the amphipod Corophium volutator. J Anim Ecol 10:77-93

Manuscript first received: January 24, 1997

Revised version accepted: March 4, 1997 